\title{
HEINONLINE
}

Citation: 87 Yale L.J. 1488 1977-1978

Content downloaded/printed from

HeinOnline (http://heinonline.org)

Thu Sep 26 15:49:27 2013

-- Your use of this HeinOnline PDF indicates your acceptance of HeinOnline's Terms and Conditions of the license agreement available at http://heinonline.org/HOL/License

-- The search text of this PDF is generated from uncorrected OCR text.

-- To obtain permission to use this article beyond the scope of your HeinOnline license, please use:

https://www.copyright.com/ccc/basicSearch.do?

\&operation $=$ go\&search Type $=0$

\&lastSearch $=$ simple\&all=on\&titleOrStdNo=0044-0094

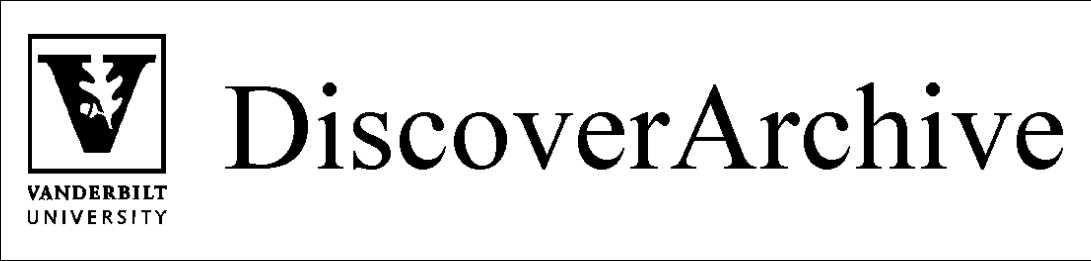

Retrieved from DiscoverArchive,

Vanderbilt University's Institutional Repository

This work was originally published as Ellen Clayton. Father and

Mother Know Best: Defining the Liability of Physicians for

Inadequate Genetic Counseling - 87 Yale Law Journal 1488

(1978). 


\section{Father and Mother Know Best: Defining the Liability of Physicians for Inadequate Genetic Counseling*}

Although genetic disorders have been recognized for centuries, recent advances in the study of human genetics often permit accurate determination of the risk that parents will have genetically defective children. ${ }^{1}$ When this information is available either before conception or during pregnancy, prospective parents may choose to prevent the birth of such defective children through contraception or abortion. Recently, courts have been called on to define the circumstances in which either the parents or the children should receive tort damages when parents are denied opportunities to prevent the birth of defective children because of their physicians' negligent failure to detect or disclose risks of genetic disorder.

Only eleven years ago, a court was unwilling to impose liability on physicians who had given inaccurate information about the risk of an environmentally induced birth defect. ${ }^{2}$ Yet many of the arguments that

- This work was supported in part by Medical Genetics Center grant GM 19513.

1. The pattern of inheritance of hemophilia has been known for more than two millenia. See M. Strickberger, Genetics 220-23 (1968). Major strides were made at the end of the nineteenth century when Francis Galton founded statistical genetics and Gregor Mendel set forth the laws that govern the heritability of traits controlled by single genes. See generally id. at 260-61; H. Sutron, An Introduction to Human Genetics 2-5, 9-10 (2d ed. 1975). The present rapid growth of knowledge in human genetics, see, e.g., McKusick, The Growth and Development of Human Genetics as a Clinical Discipline, 27 AM. J. HuMan Generics 261, 264, Table I (1975), was triggered in the 1950 s by the elucidation of the structure of DNA, the source of genetic information in most organisms, see Watson \& Crick, A Structure for Deoxyribose Nucleic Acid, 171 Nature 737 (1953). and by the identification of the correct number of human chromosomes, see Tjio \&. Levan, The Chromosome Number of Man, 42 Hereditas 1 (1956). The present knowledge of human genetics and the extent to which it is possible to predict and detect genetic disorders is discussed at pp. 1490-94 infra.

2. In Gleitman v. Cosgrove, 49 N.J. 22, 227 A.2d 689 (1967), the New Jersey Supreme Court found that a physician's failure to warn prospective parents of risks created by maternal rubella, resulting in the birth of a defective child, had not caused compensable injury. Viruses, such as those causing rubella, are only a few of the many environmental agents that can cause serious harm to the developing fetus. See Kass \& Shaw, The Risk of Birth Defects: Jacobs v. Theimer and Parents' Right to Know, 2 AM. J.L. MED. 213, 22021 (1976-77); Comment, Wrongful Birth: The Emerging Status of a New Tort, 8 SAINT MARY's L.J. 140, 144 n.20 (1976); see also S. BARR with D. Abelow, A Woman's Choice 283-85 (1977) (describing some drugs that cause fetal malformation). Since no treatment was available once a fetus had been affected by its mother's illness, the Gleitman suit was based on the mother's claim that had she known of the risks to her fetus, she would have obtained an abortion. 49 N.J. at 26, 227 A.2d at 691. The Gleitman court, however, was unwilling to approve this option. Id. at 30-31, 227 A.2d at 693-94. But see Jacobs v. 
swayed that court are no longer persuasive to courts now deciding cases involving the birth of genetically defective children. This may be due in part to the growing public awareness of the economic and emotional burden of genetic disease. ${ }^{3}$ Moreover, with dramatic constitutional developments expanding the right to choose not to procreate, ${ }^{4}$ judicial reluctance to approve abortion undertaken to avoid the birth of defective children no longer seems justified. Thus, in Howard v. Lecher ${ }^{5}$ a physician had allegedly been negligent in failing to detect the parents' risk that their child would be fatally afflicted with Tay-Sachs disease. ${ }^{6}$ Although the New York Court of Appeals denied the parents' cause of action for emotional distress, ${ }^{7}$ the lower court's recognition of their claim for medical and funeral expenses incurred in the child's behalf was not even appealed. ${ }^{8}$ In Park $v$. Chessin, ${ }^{9}$ a later case based on allegations that the defendant physicians had given inaccurate genetic risk information, a New York appellate court refused to dismiss a cause of action for "injuries and conscious pain and suffering"10 brought on behalf of a child born with polycystic kidney disease, a degenerative genetic disorder that inevitably leads to early death. The child's parents were allowed to assert a claim for their medical and support expenses.

The new judicial willingness to recognize some physician liability for failure to give accurate genetic risk information has not produced

Theimer, 519 S.W.2d 846, 848 (Tex. 1975) (although court did not approve abortion, extraordinary medical expenses awarded); Dumer v. St. Michael's Hosp., 69 Wis. 2d $766,769,233$ N.W.2d 372, 374 (1975) (although legality of abortion was unclear, extraordinary expenses awarded). Some commentators have suggested that the Gleitman court's decision on tort liability should be limited to situations where abortion is unavailable. See Note, Torts Prior to Conception: $A$ New Theory of Liability, 56 NeB. L. Rev. 706, 715 (1977); Note, 10 So. Tex. L.J. 174, 178 (1968); Note, 46 TEx. L. REv. 1004, 1007-08 (1968).

3. See pp. 1496.97 infra. Congress has noted the impact of genetic disease. See H.R. Rep. No. 498, 94th Cong., 1st Sess. $18-19$ (1975), reprinted in [1976] U.S. Code Cong. \& AD. News 709, 726-27 [hereinafter cited as House REPORT with page citations to [1976] U.S. CODE CoNG. \& AD. News].

4. See, e.g., Carey v. Population Servs. Int'l, 431 U.S. 678 (1977) (striking down law limiting sale and advertisement of contraceptives); Roe v. Wade, 410 U.S. 113 (1973) (first decision sustaining limited right to elective abortion); Eisenstadt v. Baird, 405 U.S. 438 (1972) (first recognition of contraception as individual right).

5. 42 N.Y.2d 109, 366 N.E.2d 64, 397 N.Y.S.2d 363 (1977), aff'g 53 App. Div. 2d 420, 386 N.Y.S.2d 460 (1976).

6. The manifestations of this disorder, which inevitably causes death by the age of four or five years, are discussed at 53 App. Div. 2d 420, 426-27, 434-35, 386 N.Y.S.2d 460, 464, 469 (1976) (Margett, J., dissenting). See H. Sutron, supra note 1, at 202-03.

7. Howard v. Lecher, 42 N.Y.2d 109, 110-13, 366 N.E.2d 64, 64-66, 397 N.Y.S.2d 363 , $364-66$ (1977).

8. 42 N.Y.2d 109, 115, 366 N.E.2d 64, 67-68, 397 N.Y.S.2d 363, 367 (1977) (Cooke, J., dissenting).

9. 60 App. Div. 2d 80, 400 N.Y.S.2d 110 (1977).

10. Id. at 87-88, 400 N.Y.S.2d at 114 (1977). Interestingly, the Park court was the same one that had denied the Howard parents' cause of action for emotional pain and suffering. 
consistent results. In some cases, courts have permitted only the parents to bring suit, while in others both parents and defective children have been allowed to sue. ${ }^{11}$ When courts have reached the question of defining the duty of physicians to detect and to disclose genetic risks, the standards promulgated have often limited inappropriately the scope of physicians' liability. ${ }^{12}$ Finally, even cases in which liability has been imposed have recognized differing types and measures of damages for similar injuries. ${ }^{13}$

This Note provides a more coherent method for analyzing such cases. Part I discusses the process of identifying and advising prospective parents who risk having genetically defective children so that they may make better informed procreative choices. Part II argues that imposing tort liability on individual physicians can best vindicate the social interest in reducing the incidence of genetic defects; it also contends that only causes of action asserted by parents of children with such disorders should be sustained. Part III proposes a set of requirements, based largely on existing tort doctrines, for upholding such causes of action and sets forth principles for determining the measure of damages for negligent genetic counseling by physicians.

\section{Genetic Counseling and Parental Choice}

\section{A. The Nature and Predictability of Genetic Disease}

Every individual's characteristics are determined in part by his unique genetic makeup. ${ }^{14}$ Although most inherited traits are benign,

11. Compare Karlsons v. Guerinot, 57 App. Div. 2d 73, 394 N.Y.S.2d 933 (1977) (sustaining parents' cause of action for emotional distress but denying claims brought on behalf of child with Down's Syndrome) with Park v. Chessin, 60 App. Div. 2d 80, 400 N.Y.S.2d 110 (1977) (upholding parents' claims of medical and support expenses incurred on infant's behalf and cause of action of child born with polycystic kidney disease). See pp. 1500-03 infra (arguing that only parents' causes of action should be recognized).

12. See notes 80 (contending that court in Karlsons v. Guerinot, 57 App. Div. 2d 73, 394 N.Y.S.2d 933 (1977), unwisely rejected guidance from informed consent cases in defining physician's duty of disclosure) \& 82 (suggesting that court in Park v. Chessin, 60 App. Div. 2d 80, 400 N.Y.S.2d 110 (1977), inappropriately restricted doctor's duty to disclose genetic risk information) infra.

13. Compare Becker v. Schwartz, 400 N.X.S.2d 119 (App. Div. 197\%) (court awarded total costs of raising and institutionalizing child) with Howard v. Lecher, 42 N.Y.2d 109, 366 N.E.2d 64, 397 N.Y.S.2d 363 (1977), aff'g 53 App. Div. 2d 420, 386 N.Y.S.2d 460 (1976) (trial court awarded extraordinary medical and funeral expenses incurred in caring for child with Tay-Sachs disease).

14. In many cases, of course, an affected person's environment may also be a cause of his disorder. For example, the mental retardation normally caused by phenylketonuria (PKU) apparently can be prevented simply by altering the diet for the first several years of life. H. Sutron, supra note 1, at 195-99, 480-83; see generally L. C.1vali.I-Srorza \& W. Bodmer, The Genetics of Human Populations 508-627 (1971). 


\section{this Note will focus only on those that are unquestionably harmful. ${ }^{15}$ The degree of risk for many of these deleterious traits can accurately be defined even though the actual mechanism by which a defect produces its effect may be obscure. ${ }^{16}$}

15. Hundreds and possibly thousands of deleterious genetic defects are known. Three disorders that are inevitably lethal are the Tay-Sachs and polycystic kidney diseases, see p. 1489 supra, and cystic fibrosis. P. Reilly, Genetrcs, Law, and Social Policy 2 (1977). Other serious but generally nonfatal genetic disorders include hemophilia; Down's Syndrome, characterized by mental retardation and a variety of physical stigmata, see W. Nyhan \& N. Sakati, Genetic and Malformation Syndromes in Clinical Medicine 117-23 (1976); and sickle cell anemia, a severe blood disorder punctuated by painful "sickling crises," see Forguson, Sickle Cell Anemia-The Neglected Disease, in Sickle Cell ANemiaThe Neglected Disease 7-13 (F. Olafson \& A. Parker eds. 1973). For a discussion of the legal status of less harmful or even benign genetic traits, see p. 1506 \& note 76 infra.

16. This risk can best be predicted for single-gene (Mendelian) traits, defined as those exhibiting certain simple patterns of inheritance. As of 1975 , more than 2000 of these traits, including such serious disorders as hemophilia, Tay-Sachs disease, sickle cell anemia, and Duchenne-type muscular dystrophy, had at least tentatively been identified. See V. McKusick, Mendelian Inheritance in Man: Catalogs of Autosomal Dominant, Autosomal Recessive, and X-Linked Phenotypes xii (4th ed. 1975). The risk of recurrence can generally be deduced from analysis based on two overlapping pairs of categories: dominance versus recessiveness and autosomal versus sex-linked. If a person with one normal and one defective gene is affected, the altered gene is dominant; if the individual is unaffected, the defective gene is recessive. A gene located on the $X$ or $Y$ chromosomes is said to be sex-linked; genes on the non-sex chromosomes are said to be autosomal. In turn, both dominant and recessive genes can be either autosomal or sex-linked. For examples of the inheritance patterns that follow from these classifications, see A. EMERY, ELEMENTS of Medical Genetics 94-107 (3d ed. 1974); H. Sutron, supra note 1, at 342-49.

Occasionally, a single-gene defect may be caused by a mutation in one parent's gametes (eggs or sperm). When such an event has occurred, the risk that the disorder will reappear in later-born siblings may be very difficult to ascertain. Where a dominant trait is so harmful that the affected individual's ability to reproduce is either diminished or eliminated, new mutations become the major or only source of the disorder. For a discussion of the impact of new mutations generally, see W. FuhrmanN \& F. Vogel, Genetic Counseling 26-30 (2d cd. 1976); H. Surron, supra note 1, at 301-11.

Polygenic disorders, those caused by the interaction of two or more genes, include abnormalities in the early development of the neural tube, the precursor to the brain and spinal cord, often resulting in anencephaly, an inevitably lethal trait, or spina bifida, which may be fatal and ordinarily leads to physical handicap or, more rarely, to mental retardation in those who survive. A. EMERY, supra at 127-28; Editorial, Screening for Neural-tube Defects, 1 (8026) LANCEr 1345 (1977). The only basis for predicting the recurrence of polygenic traits is inference from observed patterns of inheritance of the disorder, a technique that is frequently inexact. It generally appears that as the number of affected family members increases, the risk to future offspring also rises. A. EMERY, supra at 108-11.

Gross chromosomal anomalies, variations in the number or the structure of human chromosomes, are generally highly deleterious; an estimated $36 \%$ of all spontaneous abortions result from such abnormalities. National Institute of Health, U.S. Dep'T of Health, Educ. \&. Welfare, What Are the Facts About Genetic Disease?, Pub. No. 74-370 6 (1974) [hereinafter cited as DHEW REPORT]. The risk of the structural variants is as mathematically predictable as that of the single-gene defects. Although such anomalies have little or no effect on the individual in whom they arise, they may pose a serious threat of major birth defect to any of that person's children. One rare chromosome alteration (called 21/21 translocation) causes Down's Syndrome in all the carrier's offspring. W. NYHAN \& N. SAKATI, supra note 15, at 121 .

The incidence of genetic defects caused by the presence of an additional chromosome, 
Until about a decade ago, methods of detecting and predicting the occurrence of such traits were often inexact. Even when a genetic defect appeared in the families of a couple who wished to have children, a reliable evaluation of the risk of recurrence of the undesired trait was seldom possible. ${ }^{17}$ Predictions were often based solely on the pattern of a trait's occurrence among an affected individual's family; ${ }^{18}$ this method was at times supplemented by more general population data derived from empirical observation of other families with afflicted relatives. ${ }^{19}$ Unless a healthy couple had already had an affected child, there could be no certainty of actual risks, and no means were available to detect the presence of defects in the fetus.

Ability to forecast genetic disorders has expanded dramatically. The mode of inheritance has been determined for an increasing number of traits, and biochemical tests have been developed that allow more definite preconception predictions for many types of genetic risk. ${ }^{20}$ These advances permit properly advised prospective parents to learn of

see, e.g., id. at 117-23 (Down's Syndrome), 105-08 (Trisomy 18), 154-57 (Klinefelter's Syndrome), seems to rise with increasing maternal age. Almost $40 \%$ of the children with Down's Syndrome are born to women over 40 years of age even though less than five percent of all childbirths occur among such women. C. Stern, Principles of Human Genetics 112-13 (3d ed. 1973). Even these women, however, individually have only a one to two percent chance of bearing an infant with this disorder. H. SurroN, supra note 1 , at 62-63. Yet other types of numerical chromosomal variants, such as Turner's Syndrome, caused by the presence of only one $X$ chromosome, show no correlation with increasing maternal age. W. NYhaN \& N. SAKATI, supra note 15 , at $145 ;$ H. SuTTON, supra note 1 , at 71.

17. Couples closely related by blood might also have sought out information about genetic defects. Both consanguineous matings and prospective parents who have relatives with genetic disorders face the possibility of elevated genetic risk because blood relatives are likely to have some harmful recessive genes in common. The probability that any particular gene will be shared declines as the relationship becomes more distant. See W. Fuhrmann \& F. Voger, supra note 16 , at $\mathrm{I}-6,108-15$ (genetic risk posed by consanguinity insignificant unless mates are at least first cousins).

18. The effectiveness of this type of study is limited because accurate information is often difficult to obtain. See Fraser, Survey of Counseling Practices, in Ethical Issues in Human Genetics 7, 12 (B. Hilton, D. Callahan, M. Harris, P. Condliffe \& B. Berkley eds. 1973) [compilation hereinafter cited as ETHICAL Issues].

19. This method must still be relied on when there exists no well-tested model of heritability on which to base more definite predictions. The approach is used in analyzing polygenic traits, many chromosomal anomalies, and other disorders in which genetic factors may or may not be implicated. See note 16 supra. See also Nitowsky, Genetic Counseling: Objectives, Principles, and Procedures, 19 Clinical OBstetrics \& Gynecology 919, 932 (1976). Tables listing the empirical risks of some common disorders are given in A. EMERY, supra note 16, at 200, and W. FuhrmanN \& F. Vocec, supra note 16, at 86.88, but such data often have limited validity. $1 d$. at 85 .

20. See notes 1 \& 16 supra. Even this new knowledge has not provided the explanation for the empirically observed but nonspecific two to three percent risk of serious birth defects at each pregnancy. Nitowsky, supra note 19, at 938. These biochemical tests can detect carriers of any of 91 recessive genes. W. Fuhrmann \& F. VoGEL, supra note 16, at 44-50, Table 5.1. 
some elements of their risk of having genetically defective children in time to include this factor in their childbearing plans.

Recently developed technology that can accurately detect a large number of defects in a three and one-half to four-month-old fetus allows prospective parents at risk new freedom in deciding whether to procreate. Amniocentesis ${ }^{21}$ and ultrasonography ${ }^{22}$ are the best refined of these techniques. Along with the newly expanded availability of abortion, they can often allow prospective parents selectively to abort fetuses actually afflicted with genetic disorders. ${ }^{23}$ Unhappily, it is at

21. In this procedure, a long needle is inserted into the mother's uterus, and a sample of amniotic fluid containing living fetal cells is removed. These cells are then placed in culture to grow so that further tests can be performed. W. FuHRMANN \& F. VocEL, supra note 16, at 91-92. The sex of the fetus as well as the presence of gross chromosomal anomalies, see note 16 supra, can be determined by karyotype analysis, a procedure in which the number and structure of chromosomes are examined after staining at the time of cell division. A. EMERY, supra note 16, at 54-59. Prenatal diagnosis is at least potentially available for approximately 60 to 90 metabolic defects, including Tay-Sachs disease, Golbus, The Antenatal Detection of Genetic Disorders, 48 Onsterrics \& Gynecology 497, 500-01 (1976); Milunsky, Prenatal Diagnosis of Genetic Disorders, 295 NEw Enc. J. MED. $377,378(1976)$, and for the neural tube defects such as anencephaly and spina bifida. Editorial, supra note 16; United Kingdom Collaborative Study on Alpha-Fetoprotein in Relation to Neural-Tube Defects, Maternal Serum-Alpha-Fetoprotein Measurement in Antenatal Screening for Anencephaly and Spina Bifida in Early Pregnancy, 1 (8026) LANCET 1323 (1977).

Recent studies indicate that amniocentesis is highly accurate and represents a combined risk of less than one percent of complications ranging from spontaneous abortion and fetal death to amniotic fluid leakage and maternal infection. See, e.g., NICHD National Registry for Amniocentesis Study Group, Midtrimester Amniocentesis for Prenatal Diagnosis, 236 J. AM. MEd. A. 1471,1472 (1976) $(99.4 \%$ accuracy in 1040 cases, but even this rate may be too low due to tragic consequences of both false positive and false negative diagnoses); Simpson, Dallaire, Miller, Siminovich, Hamerton, Miller \& McKeen, Prenatal Diagnosis of Genetic Disease in Canada: Report of a Collaborative Study, 115 Canadian MEd. A.J. 739 (1976) (99.4\% accuracy in 1223 cases).

Fetoscopy, a variant of amniocentesis involving the addition of an optical system to permit the physician to look inside the uterus, can be used to obtain samples of fetal blood so that the presence of various hemoglobin disorders, such as sickle cell anemia, can be detected. See Alter, Modell, Fairweather, Hobbins, Mahoney, Frigoletto, Sherman \& Nathan, Prenatal Diagnosis of Hemoglobinopathies, 295 NEw ENG. J. MED. 1437 (1976); Mahoney \& Hobbins, Fetoscopy and Fetal Biopsy, in Generic Counseling 495 (H. Lubs \& F. de la Cruz eds. 1977) [compilation hereinafter cited as Generic Counseling].

22. The increasing sophistication in the use of ultrasound to detect anatomical abnormalities including such polygenic traits as the neural tube defects is particularly desirable since the technique seems to present no discernable risk to the fetus. Hirschhorn, Prenatal Diagnosis of Genetic Disease, in Developmental Genetics 87, 93 (C. Fenoglio, R. Goodman \& D. King eds. 1976) [compilation hereinafter cited as Devctopmental GeNETICs]. The use of this procedure for placental localization and detection of the presence of twins is also frequently cited as a necessary step for successful amniocentesis. See Simpson, Dallaire, Miller, Siminovich, Hamerton, Miller \& McKeen, supra note 21, at 741, 745. But cf. NICHD Study Group, supra note 21, at 1473, 1475 (although study did not show ultrasound to be beneficial aid to amniocentesis, authors suggested that it might be valuable when used properly).

23. When the feared genetic disorders are defects such as the chromosomal anomalies, anatomical abnormalities, and a wide variety of metabolic defects that can be directly detected in utero, there is very little risk that healthy fetuses will accidentally be aborted. 
present impossible to detect all genetic defects in utero, ${ }^{24}$ including the most common genetic disease in the United States, cystic fibrosis. ${ }^{25}$

\section{B. Procreative Decisionmaking in Genetic Counseling}

The availability of means to determine in many cases the risk that genetically defective children will be born adds a new dimension to parental decisions regarding childbearing. When advised that risk exists, prospective parents can consider this factor in choosing whether or not to employ contraception or to seek abortion. ${ }^{28}$ Prospective parents, however, cannot be expected to obtain this knowledge on their own; the risk must be detected by medical experts and effectively communicated to the prospective parents. In part, the function of providing genetic information has been assumed by publicly and privately funded programs in family planning and genetic screening. ${ }^{27}$ Generally, however, prospective parents rely on private physicians as their first, and often sole, source of such knowledge. ${ }^{28}$

See notes $21 \& 22$ supra. In some cases, however, it may be known that a woman carries a sex-linked recessive disorder that cannot be detected in utero. Since her sons but not her daughters have a $50 \%$ chance of being afflicted, she can avert the birth of children with the defect by using amniocentesis to determine the sex of developing fetuses, see note 21 supra, and aborting all males. This process thus entails a $50 \%$ risk that any aborted male was actually unaffected.

24. Indeed, the technology necessary for prenatal diagnosis is sufficiently expensive and complex that it is ordinarily used only to test for those traits for which a fetus is known to be at risk. See National Academy of Sciences, Genetic Screening: Programs, Principles ANd Research 134 (1975) (Down's Syndrome); Editorial, supra note 16 (neural tube defects).

25. See Editorial, Screening for Cystic Fibrosis, 1 (6061) BRIT. MED. J. 596 (1977). But cf. P. ReIlly, supra note 15, at 23, 26 (suggesting that breakthroughs are likely in both carrier detection and prenatal diagnosis for cystic fibrosis).

26. A couple's risk of having defective children, when caused by the presence of an altered gene in the prospective father, can be averted by using another man's sperm, implanted by artificial insemination (AID), to fertilize the woman's ova. See P. REILLY, supra note 15, at 190-221; Lubs, Artificial Insemination, in Genetic Counseling, supra note 21 , at 573 .

27. A wide variety of public health professionals working in family planning and prenatal and mother-child health care programs often refer clients who are concerned about the possibility of genetic defects to local genetics clinics. See Naylor, Genetic Screening and Genetic Counseling: Knowledge, Attitudes, and Practices in Two Groups of Family Planning Professionals, 22 Soc. Blolocy 304, 313 (1975). In a growing number of clinics and programs dealing specifically with human genetics, genetics associates who have participated in masters' degree programs in genetics and counseling techniques, social workers, and nurses are providing the actual counseling once the nature of the prospective parents' genetic risk is clear. See P. ReILly, supra note 15, at 161-62, 175-82 (with increasing demand for genetic counseling, four genetic associates may be required for each physician-medical geneticist practicing in 1985); Lubs \& Lubs, Changing Patterns of Genetic Counseling, in Developmental Genetics, supra note 22, at 102, 115 (discussing diversity of backgrounds of nonphysician personnel); see generally note 66 infra (standard of care to be exercised by such personnel).

28. See Fraser, Genetics as a Health-Care Service, 295 NEw Eng. J. MED. 486 (1976); Kushnick, When to Refer to the Geneticist, 235 J. Ax. MED. A. 623 (1976); Rowley, 
Genetic counseling involves informing prospective parents about both the nature of their genetic risks and the way in which such knowledge can be integrated into their procreative plans. Educating prospective parents about such possibilities presents peculiar difficulties, in part due to the need to convey technical information. ${ }^{29}$ Additional problems arise in determining how far counselors should go in directing prospective parents toward a particular procreative choice. ${ }^{30}$ The counselors' views may be colored not only by their subjective perceptions of the particular genetic disorders, but also by a tendency to emphasize the social impact of defective children, both as a present burden on health-care resources and as a possible contribution to the future deterioration of society's genetic composition..$^{31}$ In contrast, prospective parents ordinarily place greater weight on the potential

Genetic Screening: Whose Responsibility?, 236 J. AM. MEd. A. 374 (1976); cf. Gordis, Childs \& Roseman, Obstetricians' Attitudes toward Genetic Screening, 67 AM. J PuB. HeALTh 469 (1977) (suggesting that even use of public genetic screening programs may significantly be affected by attitudes of private physicians). But see note 41 infra (old-time family doctor who knows patients intimately no longer typical of medical practice).

29. The inability of prospective parents to grasp the likelihood of and the physical and emotional burden associated with a given defect is often a fundamental barrier to genetic counseling. Griffin, Kavanagh \& Sorenson, Genelic Knowledge, Client Perspectives, and Genetic Counseling, 2 Soc. WORK IN Health Care 171, 174 (1976-1977); Leonard, Chasc \& Childs, Genetic Counseling: A Consumers' View, 287 NEw ENG. J. MED. 433, 438 (1972). Thus part of the counselor's efforts may include teaching the prospective parents some basic concepts of probability and human biology and genetics. Yet when, due to the birth of a defective child, parents have sought genetic counseling, the counselor must often help them cope with their emotional shock before he can even begin to explain the technical nature of their genetic risk. Otherwise, the parents' distress may make them totally un. receptive to the genetic information being given. Antley, Variables in the Outcome of Genetic Counseling, 23 Soc. Bıology 108, 113 (1976); Griffin, Kavanagh \& Sorenson, supra at $174-75$.

30. Compare Capron, Informed Decisionmaking in Genetic Counseling: $A$ Dissent to the "Irongful Life" Debate, 48 IND. L.J. 581, 603 (1973) (counselor should give prospective parents sufficient information to place them in "position of informed decisionmakers") and Waltz \& Thigpen, Genetic Screening and Counseling: the Legal and Ethical Issues, 68 Nw. L. Rev. 696, 735-36 (1973) (same) with Motulsky, Brave New World?, 185 ScIENcE 653, 657 (1974) (citing Professor Childs on personal communication) (prospective parents may often want advice about desirability of procreation) and Shaw, Genetic Counseling, 184 SCIENCE 75I (1974) (counselors are advocates for what they perceive to be "best" procreative choice). Some counselors who espouse parental autonomy may nonetheless structure, often unconsciously, their presentation of genetic information to influence prospective parents toward what the counselor perceives as the "right" procreative choice. Sorenson, Sociological and Psychological Factors in Applied Human Genetics, in ETHICAL Issues, supra note 18, at 283, 295-96; see WV. FuHRMANN \& F. VoGEL, supra note 16, at 126 (impossibility of complete objectivity).

31. P. ReILLY, supra note 15, at 157-59 (discussing survey of hundreds of genetic counselors showing that many consider such factors as "the possible societal burden of the defective child," possible dysgenic effects of couple's procreation, and their own perception of burden of defect on individual and family). Contra, Motulsky, supra note 30, at 657 ("[M] the gene pool.") Studies have shown that the predicted degeneration of the gene pool will generally be minimal for the foreseeable future. See H. Surton, supra note 1, at 471-73; Crow, Population Perspective, in ETHICAI Issues, supra note 18, at 73, 76-79. 
impact on their families by balancing a desire for children against their understanding of the burden of caring for a defective child. ${ }^{32}$

Genetic counseling by physicians or other personnel exists within a general framework of parental autonomy since the prospective parents will bear the consequences of their procreative choices. Observations that prospective parents often choose against procreation when they believe that their children might be seriously defective ${ }^{33}$ suggest that ensuring the flow of genetic risk information will also reduce the social burden of genetic disease. However, the clarification of choices and values encouraged by the counseling process and, indeed, the possibility of action to avoid the birth of defective children are entirely lost when, through the negligence of physicians, genetic risks are not detected and communicated to prospective parents.

\section{The Imposition of Tort Liability When Doctors Have Inade-} quately Informed Parents About Their Genetic Risk

\section{A. The Case for a Medical Malpractice Approach}

Genetic defects represent an increasingly large part of the overall national health care burden. ${ }^{34}$ For the individual, his family, and society as a whole, the cost of medical care for persons afflicted with these defects is enormous. ${ }^{35}$ In addition, the emotional impact on the

32. See Lebel, Responsibility in Genetic Decisions, 1 BloEthics Northwest 4 (1977) (suggesting that both personal and societal factors are considered by prospective parents); cf. Griffin, Kavanagh \& Sorenson, supra note 29, at 175-76 (prospective parents may also face problems in learning to use birth control and adjusting their desires for more children). The disclosure of genetic risk information by physicians should be governed by what reasonable prospective parents would want to know in making their procreative decisions. See pp. 1506-08 infra.

33. P. Rerlly, supra note 15, at 23; Antley, supra note 29, at 110. Presumably, prospective parents warned of a risk of genetic defect before the birth of an afflicted child would also weigh carefully the severity of the disorder although the emotional impact of the risk, as opposed to the reality of a defective child, is likely to be much less. $C f$. Leonard, Chase \& Childs, supra note 29, at 437 (parents of children afflicted with nongenetic but highly burdensome defects often choose against further procreation even though there is no particular risk that defect will recur in afterborn children).

34. Although genetic defects are increasingly important as a source of ill health in people of all ages, this is particularly noticeable in diseases of the young. It has been estimated that slightly less than $20 \%$ of all pediatric hospitalizations, see Day \& Holmes, The Incidence of Genetic Disease in a University Hospital Population, 25 AM. J. HUMAN GENETICs 237, 245 (1973), and over $40 \%$ of all childhood deaths, see P. ReILly, supra note 15 , at 15-16, are caused at least in part by genetic factors.

35. The cost of treatment for a hemophiliac can run to $\$ 12,000$ per year. See House REPORT, supra note 3 , at 727. It costs $\$ 20,000$ to $\$ 40,000$ per year to care for a child afflicted with Tay-Sachs disease until his death. Id. Often, the treatment required is not only expensive but also extremely unpleasant to the child. The diet necessary during early childhood for a person with PKU to prevent severe mental retardation, see note 14 supra, 


\section{family of the birth of a defective child can be devastating. ${ }^{36}$}

Since there is no effective treatment for most genetic defects, ${ }^{37}$ control of genetic disease may be achieved only by preventing the birth of children with these disorders. ${ }^{38}$ Recently, the social interest in avoiding

a relatively minor intervention, costs from $\$ 8,000$ to $\$ 16,000$ per year, see DHEW REPORT, supra note 16, at 27 , and its taste and smell have caused it to be described as a "really miserable" regimen. L. Aucenstein, Come, Let Us Play God 27 (1969).

Although it is difficult to assess accurately the overall economic burden of genetic defects, see NATIONAL ACADEMY of ScIENces, supra note 24, at 200-12, the annual cost of caring just for all persons afflicted with Down's Syndrome has been estimated to be at least one billion dollars. See House REPORT, supra note 3, at 727; P. REILLY, supra note 15 , at 18 .

36. The desire to have children is often deeply ingrained, and most prospective parents never seriously anticipate the possibility that their child might be stricken with birth defects. Antley, supra note 29, at 112-15. Consequently, the birth of such a child often causes the parents to feel "shock and denial, anxiety, anger and/or guilt, and depression." Griffin, Kavanagh \& Sorenson, supra note 29, at 174, 177 (citing Faleck \& Britton, Phases in Coping: The Hypothesis and Its Implications, 21 Soc. Brology I (1974)); see Blumberg, Golbus \& Hanson, The Psychological Sequelae of Abortion Performed for a Genetic Indicalion, 122 AM. J. OBSTETRICs \& GYNecolocy 799, 806 (1975).

37. House REPORT, supra note 3, at 727-28; P. REILLY, supra note 15, at 22; Motulsky, supra note 30 , at 659 . The types of available treatments are summarized in A. EMERY, supra note 16 , at 206 , Table XXIII.

38. P. Reilly, supra note 15, at 22-26; cf. Motulsky, supra note 30, at 662 (selective abortion rather than gene therapy will necessarily be major approach to prevention of birth defects for foreseeable future).

An early response was state legislation in the first part of this century compelling the sterilization of persons thought likely to have children with disorders such as "idiocy" and "criminality." See, e.g., Act of April 16, 1912, ch. 445, 1912 N.Y. LAws 924, 925 (authorizing sterilization if person's children would have "an inherited tendency to crime, insanity, fecble-mindedness, idiocy or imbecility"; law invalidated in Osborn v. Thomson, 103 Misc. 23, 169 N.Y.S. 638 (Sup. Ct.), aff'd, 185 App. Div. 902, 171 N.Y.S. 1094 (1918)). In many cases, the individual to be sterilized did not receive even minimal procedural rights such as notice or a hearing. Shaw, Procreation and the Population Problem, 55 N.C.L. REv. 1165,1181 n.119 (1977).

Although these early laws were occasionally invalidated by courts, see, e.g., Davis v. Berry, 216 F. 413 (S.D. Iowa 1914), vacated as moot, 242 U.S. 468 (1917) (vasectomy is cruel and unusual punishment); Osborn v. Thomson, 103 Misc. 23, 169 N.Y.S. 638 (Sup. Ct.), aff'd, 185 App. Div. 902, 171 N.Y.S. 1094 (1918) (denial of equal protection to sterilize only those who are in confinement), the Supreme Court upheld Virginia's eugenic sterilization law in Buck v. Bell, 274 U.S. 200 (1927) (statute mandated extensive procedural protection). The Court reasoned that "society can prevent those who are manifestly unfit from continuing their kind." Id. at 207. The result reached in Buck has been tacitly affirmed by the Supreme Court as recently as 1973 , see Roe v. Wade, 410 U.S. 113,154 (1973). Yet the use of involuntary sterilization has waned. See P. REILLY, supra note 15, at 126 (decline beginning in mid-1950s). Indeed, it has been determined that many socially undesirable traits are not inherited. Lederberg, State Channeling of Gene Flow by Regulation of Marriage and Procreation, in GeNETrCs AND THE LAW 247, 261-62. (A. Milunsky \& G. Annas eds. 1976) (much mental retardation caused by nongenetic factors; even heritable forms only rarely preventable by eugenic sterilization laws); Shaw, supra at 1182-83. Findings of nonheritability have been cited as a reason for declaring cugenic compulsory sterilization statutes to be unconstitutional. See Skinner v. Oklahoma, 316 U.S. 535, 542 (1942) (striking down law mandating sterilization of persons convicted of some but not all types of felonies on ground that statutory distinction had no "significance in eugenics" and was therefore in violation of equal protection). Although the Skinner Court explicitly distinguished Buck v. Bell, 274 U.S. 200 (1927), on the ground that the operations validated in Buck might enable a previously institutionalized person 
genetic disorders has been served by taking steps to ensure that prospective parents are advised about their genetic risk. One trend has been the establishment of federal and state screening programs based on voluntary participation by adults to detect carriers of specific harmful traits. $^{39}$ Yet economic reality dictates that such screening programs can never become the primary source of genetic risk information. Their usefulness is limited to testing for predictable defects that occur relatively frequently within some easily defined target population. ${ }^{40}$

to return to society, dicta throughout Skinner suggested that the Court would have up. held a statute that provided for the sterilization only of those persons who were likely to have children with genetic defects. Id. at 542, 544 (Stone, C.J., concurring), 546 (Jackson, J., concurring).

39. The present programs and future prospects for screening to detect carriers of genetic defects are discussed at length in Natronal Academy of Sciences, supra note 24, at 116-223; P. ReIlly, supra note 15, at 62-120. In 1976, Congress passed an omnibus bill entitled the National Sickle Cell Anemia, Cooley's Anemia, Tay-Sachs and Genetic Diseases Act providing federal funds to support state and local carrier detection programs and to set up screening and counseling within the Public Health Service. Pub. L. No. 94 278, 90 Stat. 407 (1976) (codified at 42 U.S.C.A. $\$ \$ 300 \mathrm{~b}$ to $300 \mathrm{~b}-5$ (West Supp. 1977)). Maryland has also passed a far-reaching genetic diseases act. Commission of Hereditary Disorders Act, 1973 Md. Laws 231, 695 (codified at 43 MD. Code ANN. \$\$ 814-821 (Supp. 1977)). California has recently approved a bill providing for a two-year pilot program for outreach in nondirective genetic counseling. 1977 Cal. Legis. Serv. 215. Tay-Sachs screening has generally been undertaken on the local level in more than 50 major cities throughout the nation. See Kaback, Detection of Tay-Sachs Disease Carriers: Lessons and Ramifications, in Genetic Counseling, supra note 21, at 203-04. Recently, however, three states have begun providing support for these programs. See P. REILLY, supra note 15, at 110-11. Screening programs for sickle cell anemia and sickle cell trait are statutorily mandated in seventeen states. Id. at 85, Table 5 (listing statutory provisions). As of 1977,10 of these laws called for mandatory participation by blacks, although some allowed religious exemptions, and only 11 mentioned providing counseling to persons found to have the defective gene. Id.

Screening programs for certain groups of pregnant women have also been suggested. Under one proposal, the blood level of alpha-fetoprotein would be measured in all women who are 16 to 18 weeks pregnant to detect fetuses probably afflicted with neural tube defects. See Editorial, Diagnostic Amniocentesis in Early Pregnancy, 1 (6074) BrIT. MEd. J. 1430 (1977); Editorial, supra note 16; notes $21-22$ supra (techniques to confirm presence of such abnormalities).

Since the risk of many chromosomal anomalies increases with advancing maternal age, see note 16 supra, programs offering amniocentesis to older pregnant women have been proposed, see NAtional ACADEMY of SGIENCES, supra note 24, at 135, and, in a few instances, partially implemented. P. REILLY, supra note 15, at 116-18.

40. Screening programs for the Tay-Sachs gene have been limited to Ashkenazi (Eastern European) Jews and those for the sickle cell gene to blacks, groups in which these genes are present in relatively high frequency. See H. Surton, supra note 1, at 484; Annas \& Coyne, "Fitness" for Birth and Reproduction: Legal Implications of Genetic Screening, 9 FAM. L.Q. 463, 483-84 (1975). Because the sickle cell gene is also common among some other populations, the racial orientation of programs screening for that trait has resulted in the allegation that their true purpose is one of black genocide. See id. at 485. Screening programs for Down's Syndrome and other chromosomal anomalies, see note 39 supra, can be justified only when limited to pregnant women over the age of 35 years. Thus restricted, the cost of the necessary amniocentesis surveys is much lower than the cost of medical care and institutionalization that would otherwise be required. See notes $16 \& 35$ supra 
Due to the limitations of these screening programs, private physicians will continue to be the principal providers of genetic information. Indeed, where prospective parents have a personal doctor, ${ }^{41}$ his familiarity with them may make him uniquely qualified to detect and convey facts regarding the possibility of genetic defects. ${ }^{42}$ Yet, as in other areas of medical practice, a doctor may neglect the need to provide adequate genetic counseling. ${ }^{43}$ Tort law, a well-recognized means of regulating the practice of medicine, ${ }^{44}$ can be used both to establish and to limit the duty of physicians to fulfill this function. Under such a system, a doctor whose negligence results in the birth of a genetically defective child would be liable for compensatory damages. ${ }^{45}$

41. Intimate knowledge of patients and their families is no longer the norm of medical practice. Indeed, many people, especially among poor and non-Caucasian populations, receive much of their medical care from hospital outpatient clinics and emergency rooms. See Health Resources Ad., U.S. Dep't of Health, Educ. \& Welfare Public Health Service, Health United States 1975, Pub. No. 76-1232, at 293, 503 (1976). Even doctors who work in such facilities should be responsible for detecting certain types of genetic risk. See pp. 1504-06 infra. If necessary, they can and should refer prospective parents at risk to other physicians or genetics clinics for further testing and counseling.

42. See, e.g., Kushnick, supra note 28, at 624; Valentine, The Reproductive Counseling Process: Comments Based on Experience, 16 Clinical Pediatrics 233, 238 (1977).

43. For cases alleging physician negligence, see Howard v. Lecher, 42 N.Y.2d 109, 110, 366 N.E.2d 64, 66, 397 N.Y.S.2d 363, 365 (1977) (doctor failed to warn prospective parents of $25 \%$ risk of Tay-Sachs disease); Park v. Chessin, 60 App. Div. 2d 80, 400 N.Y.S.2d 110 (1977) (physicians had negligently informed parents of child with polycystic kidney disease that there was no significant risk that their future children would have this disorder).

44. One of the purposes often ascribed to tort law is general deterrence, the imposition of liability to create incentives in the direction of socially desirable behavior. See, e.g., G. Calabresi, The Costs of Accidents 73-75 (1970); 2 F. Harper \& F. James, The Law of Torts $\$ 11.5$, at $742-43$ (1956); W. Prosser, Handbook of The LAw of Torts $\$ 4$, at 23 (4th ed. 1971). Physician behavior may be shaped in part by articles discussing significant malpractice decisions that regularly appear in literature readily accessible to the medical community. See, e.g., Curran, Tay-Sachs Disease, Wrongful Life, and Preventive Malpractice, 67 AM. J. PuB. HeALTH 568 (1977) (analyzing Howard v. Lecher, 53 App. Div. 2d 420,386 N.Y.S.2d 460 (1976), aff'd 42 N.Y.2d 109, 366 N.E.2d 64, 397 N.Y.S.2d 363 (1977), and Park v. Chessin, 88 Misc. 2d 222, 387 N.Y.S.2d 204 (Sup. Ct. 1976), aff'd 60 App. Div. 2d 80, 400 N.Y.S.2d 110 (1977)); Curran, The Proper and Improper Concerns of Medical Law and Ethics, 295 NEw ENG. J. MED. 1057 (1976) (from regular column entitled "LawMedicine Notes"). Professor Posner, however, objects to the use of tort law as a means of regulating medical practice on the ground that it encourages less than optimal activities. R. POSner, Economic Analysis of Law 157-59 (2d ed. 1977).

Direct governmental regulation might provide another way to shape the behavior of physicians. A governmental agency may be slow to respond to changing conditions, however, an occurrence that would be highly problematic in regulating a rapidly expanding discipline such as human genetics. Moreover, such an approach would not provide compensation for the parties harmed by a physician's failure to give genetic counseling. Such considerations support a conclusion that tort law may be the appropriate method of governing medical practice.

45. Compensation of persons harmed by tortfeasors has been described as the primary purpose of tort law. 2 F. HARper \&. F. JAMEs, supra note 44, $\$ 25.1$, at 1299-1303; see D. Dobrs, HandBook ON the LAW of Remedies $\$ 3.1$, at 135-38 (1973); W. Prosser, supta note $44, \$ 1$, at 6 . 


\section{B. The Standing to State a Claim}

In the past, courts have been inconsistent in their willingness to recognize various causes of action based on allegedly negligent genetic counseling. ${ }^{46}$ Yet tort law can provide neither deterrence nor compensation unless it is possible for at least some of the injured parties to bring valid suits.

\section{1. "Wrongful Life"-The Child's Claim}

A wrongful life claim ${ }^{47}$ is a cause of action on behalf of a defective child asserting that he would have been better off had he never been born, thus characterizing the fact of his existence as "wrongful." 48 Few courts have been willing to recognize such claims. ${ }^{49}$ Although courts

46. There are six reported cases analyzing a physician's failure to warn of the possible occurrence of genetic defects. See Howard v. Lecher, 42 N.Y.2d 109, 366 N.E.2d 64, 397 N.Y.S.2d 363 (1977) (Tay-Sachs disease; cause of action for parents' emotional pain and suffering denied on appeal); Johnson v. Yeshiva Univ., 42 N.Y.2d 818, 364 N.E.2d 1340, 396 N.Y.S.2d 647 (1977) (no liability for failure to detect cri-du-chat syndrome); Park v. Chessin, 60 App. Div. 2d 80, 400 N.Y.S.2d 110 (1977) (polycystic kidney disease; causes of action upheld for loss of wife's services and for child's pain and suffering and medical expenses); Becker v. Schwartz, 400 N.Y.S.2d 119 (App. Div. 1977) (disorder unnamed; sustaining all causes of action asserted by parents and child except those involving emotional distress); Karlsons v. Guerinot, 57 App. Div. 2d 73, 394 N.Y.S.2d 933 (1977) (Down's Syndrome; sustaining cause of action for parents' mental anguish); Greenberg v. Kliot, 47 App. Div. 2d 765, 367 N.Y.S.2d 966, appeal denied, 37 N.Y.2d 707, 337 N.E.2d 618, 375 N.Y.S.2d 1026 (1975) (mem.) (facts summarized in Park v. Chessin, 60 App. Div. 2d 80, 93, 400 N.Y.S.2d 110, I16-18 (1977) (Titone, J., dissenting)) (Down's Syndrome; denying claim brought on child's behalf).

47. The terminology used to describe the various causes of action in cases involving the birth of defective children and in those in which a child is born due to failure of contraception or abortion is extremely confused. See Kass \& Shaw, supra note 2, at 226 n.55 (discussing some of these formulations). To avoid this quagmire, the term "wrongful life" will be used here to refer only to the child's claim. No special designation will be created to refer to the parents' claims.

48. This cause of action is predicated on the theory that had the parents known of their genetic risk, they would have chosen to use abortion or contraception to prevent the birth of that child. Because prospective parents can be expected to consider the burden borne by a genetically defective child in making their decision not to procreate, it is plausible that the affected child's injury was caused by his parents' lack of genetic risk information.

49. Greenberg v. Kliot, 47 App. Div. 2d 765, 367 N.Y.S.2d 966, appeal denied, 37 N.Y.2d 707, 337 N.E.2d 618, 375 N.Y.S.2d 1026 (1975) (mem.) (facts summarized in Park v. Chessin, 60 App. Div. 2d 80, 93, 400 N.Y.S.2d I10, 116-18 (1977) (Titone, J., dissenting)) (child born with Down's Syndrome due to alleged failure to perform amniocentesis); Karlsons v. Guerinot, 57 App. Div. 2d 73, 79-81, 394 N.Y.S.2d 933, 937-38 (197i) (Down's Syndrome); Speck v. Finegold, No. GD 76-07752, at 20 (Ct. C.P., Allegheny Cty., Pa., July 21, 1976) (child born with neurofibromatosis after failure of both vasectomy and abortion); Dumer v. Saint Michael's Hosp., 69 Wis. 2d 766, 771-73, 233 N.W.2d 372, 374-76 (1975) (rubella); Note, Torts Prior to Conception: A New Theory of Liability, supra note 2, at 714 n.40 (citing cases); Note, 13 WAKE FOREST L. Rev. 712, 712 n.5, 716 n.27 (1977) (citing cases). Contra, Park v. Chessin, 60 App. Div. 2d 80, 400 N.Y.S.2d 110 (1977) (failure to warn parents that child might have polycystic kidney disease is injury to child); Becker $v$. Schwartz, 400 N.Y.S.2d 119 (App. Div. 1977) (unnamed disorder). 
have often relied on the difficulty of measuring damages to justify their refusal to make awards in such cases, ${ }^{50}$ this explanation may mask a more fundamental judicial disbelief that such children have actually been injured by being born. ${ }^{51}$

In Park $v$. Chessin, ${ }^{52}$ a court sustained a cause of action brought on behalf of a child born with polycystic kidney disease to recover for her "injuries and conscious pain and suffering," ${ }^{33}$ a measure of damages apparently reflecting the inaccurate assumption that she could have been born healthy. ${ }^{54}$ Notwithstanding the court's holding in Park, a

50. Gleitman v. Cosgrove, 49 N.J. 22, 28-29, 227 A.2d 689, 692 (1967), relied on the argument made by a commentator that "'no comparison is possible since were it not for the act of birth the infant would not exist. By his cause of action, the plaintiff cuts from under himself the ground upon which he needs to rely in order to prove his damage.' Id. (quoting Tedeschi, On Tort Liability for "Wrongful Life", 1 IsRaEL L. Rev. 513, 529 (1966)). For other cases that use this argument, see Karlsons v. Guerinot, 57 App. Div. 2d 73, 80-81, 394 N.Y.S.2d 933, 937-38 (1977); Jacobs v. Theimer, 519 S.W.2d 846, 849 (Tex. 1975). But see Gleitman v. Cosgrove, 49 N.J. at 50-51, 227 A.2d at 704 (Jacobs, J., dissenting) (lack of logically definable damages should not bar compensation for child's defects); Park v. Chessin, 60 App. Div. 2d 80, 87-88, 400 N.Y.S.2d 110, 114 (1977) (rejecting argument that child's damages unmeasurable).

51. The majority in Gleitman v. Cosgrove, 49 N.J. 22, 30, 227 A.2d 689, 693 (1967), expressed their "felt intuition" that had they been able to ask the Gleitman child, who was severely defective in sight, speech, and hearing, whether he would rather have been aborted, "he would almost surely [have chosen] life with defects as against no life at all." Id. They went on to observe that a number of people had attained "great achievement" in spite of physical handicaps and concluded that a "child need not be perfect to have a worthwhile life." Id.

52. 60 App. Div. 2d 80, 400 N.Y.S.2d 110 (1977).

53. Id. at 88; 400 App. Div. 2d at 114. The court found that the denial of the parents' right to abortion may "be tortious to the fundamental right of a child to be born as a whole, functional human being." Id. Given the characteristics of Lara Park's defect, it was at least plausible that her life was in fact worse than nonexistence and thus a detriment to her. Infantile polycystic kidney disease is an inevitably lethal trait manifested by grossly enlarged and basically nonfunctional kidneys and by facial stigmata. See M. Sucheston \& M. Cannon, Congenital Malformations $197-202$ (1973). The first child born to the Parks died of this disorder within five hours of birth while the plaintiff second-born child lingered for two and one-half years. Park v. Chessin, 60 App. Div. 2d 80, 83, 400 N.Y.S.2d 110,111 (1977).

54. See note 53 supra. Such a postulate would be valid in prenatal injury cases claiming that tortfeasors' acts had harmed healthy fetuses. See, e.g., Dillon v. S.S. Kresge Co., 35 Mich. App. 603, 192 N.W.2d 661 (1971) (mem.) (unsanitary working conditions had allegedly caused maternal rubella, thereby injuring unborn child); Sylvia v. Gobeille, 101 R.I. 76, 220 A.2d 222 (1966) (child's injuries from maternal rubella caused by doctor's failure to prescribe preventive measures after mother had been exposed but before she had developed disease). In such cases, the measure of damages, as is generally true in instances of personal injury, is the difference between the benefits and burdens of the lives that the affected children will lead and those of the lives that they otherwise would have led. This may often be approximated by the prenatally injured children's physical and emotional pain and suffering. By contrast, children with genetic disorders are defective from the moment of conception. The only alternative to their suffering, and thus the standard against which their compensation must be determined, is no life at all. See note 50 supra. 
policy of denying wrongful life claims is appropriate. ${ }^{55}$ Even if precise determinations of damages were possible, such claims in effect allow the children to assert that they would have been better off dead than alive, a statement that contradicts deeply held beliefs in the value of life that, despite some contrary signs, ${ }^{56}$ remain strong. ${ }^{57}$

\section{The Parents' Cause of Action}

Whatever the resolution of the wrongful life issue, the parents of genetically defective children should, in some cases, be permitted to assert claims for damages. ${ }^{5 s}$ When doctors' negligence deprives prospec-

55. The majority of legal commentators does not favor awarding damages for such causes of action. See, e.g., Tedeschi, supra note 50; Comment, Liability for Failure of Birth Control Methods, 76 Colum. L. REv. 1187, 1201 n.76 (1976); Comment, supra note 2. For commentary arguing that courts should uphold wrongful life claims, see Friedman, Legal Implications of Amniocentesis, 123 U. PA. L. REv. 92, 148-55 (1974); Note, $A$ Cause of Action for "Wrongful Life": [A Suggested Analysis], 55 MINN. L. REv. 58, 80-81 (1970).

56. The debate about euthanasia and its basic assumption that there may, in fact, be times when life is not worth living indicates that this citadel is under attack. Although the increasing sophistication of medicine can now prevent the death of many severely defective children, the "rescue" may be so incomplete that the children are at best less than healthy. As a result, there have been suggestions that parents should be able to deny extraordinary medical care to certain of these newborns who face very poor prognoses even with treatment. See, e.g., Goldstein, Medical Care for the Child at Risk: On State Supervention of Parental Autonomy, 86 YALE L.J. 645, 654-58 (1977); Note, BirthDefective Infants: A Standard for Nontreatment Decisions, 30 SrAN. L. REv. 599 (1978); see also In re Quinlan, 70 N.J. 10, 355 A.2d 647 (1976) (guardian of critically ill person can choose not to have extraordinary medical care when treatment involves extensive bodily invasion and poor prognosis for improvement). Quinlan does not compel recognition of the wrongful life claim. It recognized a qualified right of an incompetent person to have life support efforts terminated. The wrongful life claim goes far beyond this limited holding. In it, the child demands compensation from another for the very fact of being born.

57. See, e.g., Stewart v. Long Island College Hosp., 58 Misc. 2d 432, 436, 296 N.Y.S.2d 41, 46 (Sup. Ct. 1968), modified, 35 App. Div. 2d 531, 531, 313 N.Y.S.2d 502, 503 (1970), aff'd mem., 30 N.Y.2d 695, 283 N.E.2d 616, 332 N.Y.S.2d 640 (1972) (prolife bias of tort law cited in holding that plaintiff-child had no cause of action against doctor who failed to perform abortion). Although only three states have laws making attempts to take one's own life illegal, see Comment, State ex rel. Swann v. Pack: Self-Endangerment and the First Amendment, 65 KY. L.J. 195, 200 n.29 (1976), many states have enacted statutes that make aiding and abetting such acts unlawful. See Schwartz, Civil Liability for Causing Suicide: A Synthesis of Law and Psychiatry, 24 VAND. L. Rev. 217, 220 n.24 (1971).

58. Prospective parents may also be harmed when, in reliance on incorrect information that they risk having children with genetic defects, they decided to undergo contraceptive sterilization or abortion. False positive diagnoses have been made even when amniocentesis, a highly accurate technique, has been used. See NICHD Study Group, supra note 21, at 1472; Simpson, Dallaire, Miller, Siminovich, Hamerton, Miller \& McKeen, supra note 21, at 744. As a practical matter, it seems unlikely that such prospective parents would discover that they had been misled, but if they did, they might well decide to bring suit against the source of the erroneous warning. Yet even if they could show that the mistake had been one of negligence, they might encounter serious difficulties in attempting to prove the extent of their injury. Where prospective parents had opted for sterilization, they presumably would need to substantiate the number of children they otherwise would 
tive parents of opportunities to avert the birth of defective children, parents suffer both economic and emotional injury. ${ }^{59}$ Until 1975, appellate courts, relying on the difficulty of measuring the parents' alleged injuries, ${ }^{00}$ refused to permit recovery on the parents' claims. Yet the elements of their requests for damages-economic $\operatorname{costs}^{61}$ and emotional distress ${ }^{62}$-are regularly treated in other areas of tort law. ${ }^{63}$

have had, a seemingly insurmountable burden of proof. Although it might appear that misguided decisions to abort would result in damages that would be more restricted but easier to measure if one assumes that the prospective parents could and would go on to have more children, such an assumption may not always be valid, especially for older women, see, e.g., Gleitman v. Cosgrove, 49 N.J. 22, 65, 227 A.2d 689, 712 (1967) (Weintraub, C.J., dissenting in part). Whatever may be the appropriate way to measure such elements of damages, misinformed prospective parents should be permitted to recoup the economic and emotional costs of undergoing the unnecessary sterilization or abortion. Evidence suggests that at least selective abortion can be an emotionally shattering experience. See Blumberg, Golbus \& Hanson, supra note 36.

59. See pp. 1496-97 supra. Of course, the elements necessary to sustain a cause of action, see pp. 1504-10 infra, must be present before any damages can be awarded.

60. See, e.g., Gleitman v. Cosgrove, 49 N.J. 22, 29.30, 227 A.2d 689, 693 (1967); Stewart v. Long Island College Hosp., 35 App. Div. 2d 531, 532, 313 N.Y.S.2d 502, 503-04 (1970), rev'g 58 Misc. 2d 432, 296 N.Y.S.2d 41 (Sup. Ct. 1968), aff'd mem., 30 N.Y.2d 695, 283 N.E.2d 616, 332 N.Y.S.2d 640 (1972); see also Terrell v. Garcia, 496 S.W.2d 124, 128 (Tex. Ct. Civ. App. 1973) (writ refused; no reversible error), cert. denied, 415 U.S. 927 (1974) (child born after failure of tubal ligation; impossibility of measuring intangible benefits of parenthood).

61. Courts have often allowed damages for economic injury to parents who bear a healthy child as a result of contraceptive failure. Among the elements of damages recovered in such cases are the medical expenses incurred in obtaining the ineffective sterilization and caused by the ensuing pregnancy, e.g., Coleman v. Garrison, 327 A.2d 757, 761 (Del. Super. Ct. 1974), aff'd, 349 A.2d 8 (Del. 1975), the economic loss associated with the birth and rearing of the child less any joy or benefit that the child might bring to the parents, e.g., Troppi v. Scarf, 31 Mich. App. 240, 255, 260-61, 187 N.W.2d 511, 518, $520-21$ (1971), and that amount of money needed to "replenish the family exchequer" so that other family members would not be economically injured by the birth of an unexpected child, e.g., Custodio v. Bauer, 251 Cal. App. 2d 303, 323-24, 59 Cal. Rptr. 463, 476-77 (1967).

A number of courts, however, have explicitly refused to allow recovery of the costs of childrearing in these circumstances. See, e.g., Coleman v. Garrison, 349 A.2d 8, 11-14 (Del. 1975); Hays v. Hall, 477 S.W.2d 402, 406 (Tex. Ct. Civ. App.), rev'd on other grounds, 488 S.W.2d 412 (Tex. 1972).

62. Although emotional distress damages have not been awarded for the birth of a healthy child following contraceptive failure, they are given in a wide variety of contexts. See, e.g., Johnson v. Statc, 37 N.Y.2d 378, 382-84, 334 N.E.2d 590, 592-93, 372 N.Y.S.2d 638, $642-43$ (1975) (plaintiff allowed to recover damages for her emotional trauma caused by being negligently and incorrectly informed that her mother had died); Clemm v. Atchison, T. \& S.F. Ry., 126 Kan. 181, 268 P. 103 (1928) (compensating mental anguish and consequent physical injuries resulting from railroad's negligent delay in shipment of corpse).

63. The economic and emotional impact of the birth of a defective child can also represent a significant injury to any prior-born children. Although courts have occasionally been willing to compensate a family as a unit for the economic burden imposed by the birth of an unplanned but healthy child, see, e.g., Custodio v. Bauer, 25l Cal. App. 2d 303, 323-25, 59 Cal. Rptr. 463, 476-77 (1967), they have uniformly rejected any causes of action brought solely on behalf of such a child's siblings. See, e.g., Aronoff v. Snider, 292 So. 2d 418, 419 (Fla. Dist. Ct. App. 1974); Cox v. Stretton, 77 Misc. 2d 155, 158-60, 352 N.Y.S.2d 834, 839-41 (Sup. Ct. 1974). This judicial attitude suggests that the siblings of a 


\section{The Standards of Liability in Tort}

\section{A. Defining the Cause of Action}

Existing cases give inadequate guidance on the necessary elements of a cause of action for parents of genetically defective children. ${ }^{64}$ Drawing on traditional tort doctrines relating to the medical standard of care and the requirement of proximate cause, ${ }^{65}$ this section offers criteria for use by the courts.

\section{The Medical Practitioner-The Duty to Detect the Risk of Genetic Disorders}

An appropriate standard of care for genetic counseling by a physician should measure both the sufficiency of the steps taken to detect genetic risks and the amount and accuracy of information provided to prospective parents. The first component pertains to the degree of medical skill exercised by the physician. ${ }^{66}$ The standard traditionally imposed is the degree of care exercised by other practitioners possessing a similar degree of skill and knowledge. ${ }^{67}$ Measured by this standard, a physician who either failed to employ or inadequately executed tests commonly performed to ascertain the likelihood of genetic defects should be found

genetically defective child should similarly be denied any individual awards of damages. They probably would have had no part in making their parents' procreative decision even had the genetic risk information been conveyed, and, from the perspective of deterrence, so long as the parents receive compensation, the recognition of the siblings' claims would likely do little to enhance the general availability of genetic counseling.

64. See, e.g., notes 80 \& 82 infra.

65. See generally 1 D. Louisel. \& H. Williams, Medical Malpractice 194-217 (1977) (essential elements of typical case in medical malpractice).

66. Although medical expertise is clearly necessary both for prenatal diagnosis, see p. 1493 and notes 21-22 supra, and for full use of a person's individual and family medical histories and of empirically derived data, see pp. 1492, 1499 supra, people who are not physicians can be trained to screen, at least initially, for certain elevated risks of genetic defect. The care that such personnel would be required to exercise in this type of risk detection would almost certainly be less than that required of a doctor.

67. See 1 D. Louisell \& H. Williams, supra note 65 , at 200.06. A classic formulation was given in Zoterell v. Repp, 187 Mich. 319, 330, 153 N.W. 692, 696 (1915) (physician must "bring and apply to the case in hand that degree of skill, care, knowledge, and attention ordinarily possessed and exercised by practitioners of the medical profession under like circumstances"). One effect of this rule has been that medical specialists acting within their specialties have been held to a higher level of treatment than that required of nonspecialists. See, e.g., Robbins v. Footer, 553 F.2d 123 (D.C. Cir. 1977) (obstetrician); Naccarato v'. Grob, 384 Mich. 248, 180 N.W.2d 788 (1970) (pediatrician). Many of the cases based on failure to warn a pregnant woman that the fetus she was carrying might be defective were brought against obstetricians. See, e.g., Gleitman v. Cosgrove, 49 N.J. 22, 227 A.2d 689 (1967) (rubella); Howard v. Lecher, 42 N.Y.2d 109, 366 N.E.2d 64, 397 N.Y.S.2d 363 (1977) (Tay-Sachs disease); see also Park v. Chessin, 88 Misc. 2d 222, 387 N.Y.S.2d 204 (Sup. Ct. 1976), aff'd, 60 App. Div. 2d 80, 400 N.Y.S.2d 110 (1977) (failure to warn prior to conception about risk of polycystic kidney disease). 
negligent. ${ }^{68}$ Because an obstetrician in his practice attempts to ensure, insofar as possible, that children will be born healthy, he should be expected to exercise greater care in detecting such risks in unborn or unconceived children than should a general practitioner or a specialist in another discipline. All specialists, however, should be knowledgeable about the genetic disorders that arise in their practice. ${ }^{69}$

When applied to a developing field of medical practice like genetic counseling, this rule may unduly limit physicians' liability. Because knowledge of human genetics is expanding rapidly, doctors should not be exonerated when they have failed to keep reasonably current in this area. ${ }^{70}$ It has long been recognized that physicians are bound to stay abreast of major medical developments, particularly those relating to areas of their special expertise. ${ }^{71}$ In evaluating the adequacy of physicians' detection of genetic risk, courts should go beyond the limits of this traditional requirement by strictly compelling doctors to be aware at least of techniques widely known within the medical community. The number of reports in the medical literature and the circulation of the journals in which they appear should be primary indicia used in this determination. ${ }^{72}$

68. It has been suggested, for instance, that a doctor who fails to offer an amniocentesis to an older pregnant woman to detect the risk of gross chromosomal anomalies has been negligent. See A. Holder, Legal Issues in Pediatrics ANd Adorescent Mindicine 32-37 (1977); P. REILLY, supra note 15, at 25 (this test in common use to detect these defects). There obviously should be no imposition of liability, however, when even a specialist in human genetics could not have predicted the occurrence of a specific defect.

69. Thus, a neurologist should know about the genetic basis of Huntington's disease. See L. WhaleY, Understanding INherited Disorders 35 (1974) (describing manifestations of this disorder).

70. A doctor who failed to use a newly developed test for genetic disorders might argue that the technique had not yet been adopted in similar communities. See, e.g., Johnson v. Yeshiva Univ., 42 N.Y.2d 818, 364 N.E.2d 1340, 396 N.Y.S.2d 647 (1977) (child with cri-du-chat syndrome, structural chromosomal anomaly, born in 1969 after mother had received genetic counseling; failure to use amniocentesis not negligent practice at that time); Park v. Nissen, No. 190033 (Cal. Super. Ct., Orange Cty., Dec. 13, 1974), reported in 31 Citation 38 (Je. 1, 1975) (child with Down's Syndrome born in 1971; jury apparently found that amniocentesis not required by community standard of care at that time). These cases might well have a different result if they arose today. See pp. 1504-05 \& note 68 supra.

71. See I D. Louisell \& H. Williams, supra note 65, at 209 (citing Leighton v. Sargent, 27 N.H. 460, 59 Am. Dec. 388 (1853), to illustrate long history of duty to "keep "p"). Although this requirement is more often mentioned in reference to specialists, see, c.g., Naccarato v. Grob, 384 Mich. 248, 253-54, 180 N.W.2d 788, 790-91 (1970) (pediatrician); Wood v. Vroman, 215 Mich. 449, 465-66, 184 N.W. 520, 525 (1921) (eye specialist), general practitioners have a similar obligation, see, e.g., Flock v. J.C. Palumbo Fruit Co, 63 Idaho 220, 241, 118 P.2d 707, 714 (1941); Brune v. Belinkoff, 354 Mass. 102, 109, 235 N.E.2d 793, 798 (1968) (dicta).

72. See Viita v. Fleming, 132 Minn. 128, 137, 155 N.W. 1077, 1081 (1916). But cf. Ciccarone v. United States, 350 F. Supp. 554, 564 (E.D. Pa. 1972), aff'd on other grounds, 486 F.2d 253 (3rd Cir. 1973) (neurologist not negligent in using diagnostic technique even though two articles had appeared in Journal of the American Medical Association about 
Even today, a physician's responsibility is often measured by the level of practice in his or similar communities. ${ }^{73}$ This proviso could limit physician liability when the community practice in perceiving genetic risks is generally lax. Yet in view of the recent erosion of the locality rule in favor of more uniform standards of care, ${ }^{74}$ an inadequate local practice should not confer immunity from liability when deviations from sound medical practice can be shown..$^{75}$

\section{The Reasonable Parent-The Physician's Duty to Inform}

Diligent physicians may uncover a wide variety of genetic risks-some grave, some insignificant. Yet it seems unreasonable to impose liability on doctors for failing to tell prospective parents of the chance that their children might have some benign or only slightly harmful genetic trait. ${ }^{76}$ Instead, in deciding whether practitioners have been negligent

risk of procedure). Courts might also want to consider the dispersal of information through such forums as medical association meetings, regional medical centers, and continuing education for physicians. See, e.g., Siirila v. Barrios, 398 Mich. 576, 615-17, 248 N.W.2d 171, 187 (1976) (Williams, J., concurring).

73. E.g., Burk v. Foster, 114 Ky. 20, 25-26, 69 S.W. 1096, 1097 (1902); Siirila v. Barrios, 58 Mich. App. 721, 724, 228 N.W.2d 801, 802-03 (1975), aff'd on other grounds, 398 Mich. $576,589,248$ N.W.2d 171, 175 (1976) (general practitioners). The main implication of the similar locality rule has been that rural practitioners have been held to a different, and presumably lower, standard of care than a doctor in an urban center. In addition, a physician might be responsible for knowing more about local diseases than would an outsider.

74. In some instances, courts have stated that the level of care practiced in similar communities is only one factor to be considered in determining the issue of negligence. See, e.g., Douglas v. Bussabarger, 73 Wash. 2d 476, 488-90, 438 P.2d 829, 837-38 (1968); Shier v. Freedman, 58 Wis. $2 d$ 269, 283-84, 206 N.W.2d 166, 174 (1973). Other courts have gone beyond that limit and have applied a uniform standard of care. See, e.g., Robbins v. Footer, 553 F.2d 123, 129 (D.C. Cir. 1977) (specialists); Shilkret v. Annapolis Emergency Hosp. Ass'n, 276 Md. I87, 200-01, 349 A.2d 245, 253 (1975) (all physicians).

75. There is some recognition, completely apart from the workings of the locality rule, that even compliance with a high level of practice may not always be adequate. See, e.g., Faulkner v. Pezeshki, 44 Ohio App. 2d 186, 191, 337 N.E.2d 158, 163 (1975); Helling v. Carey, 83 Wash. 2d 514, 519, 519 P.2d 981, 983 (1974). In such cases, the courts essentially ignore the medical standard and instead requirc physicians to conform to a judicially imposed reasonable prudence test, often raising serious questions about the proper relationship between the courts and the medical profession. The proposal in this Note does not face such difficulties since it would only compel doctors to comply with present standards of medical care in detecting risks of genetic defects.

76. Some prospective parents will choose to use amniocentesis to abort selectively any fetuses that either have detectable minor defects or are of the "wrong" sex. See Fraser \& Pressor, Attitudes Of Counselors In Relation To Prenatal Sex-Determination Simply For Choice of Sex, in Generic Colinseling, supra note 21, at 109. Other prospective parents who would have made similar decisions had they been aware of the capabilities of prenatal diagnosis are at least plausibly injured by their physicians' failure to inform them of this possibility. Although courts have sometimes permitted parents to receive compensation from doctors who had failed to diagnose a woman's pregnancy in time for her to obtain an abortion, see, e.g., Ziemba v. Sternberg, 45 App. Div. 2d 230, 357 N.Y.S.2d 265 (1974), arguments can be made against awarding damages to the parents of a child whose 
in failing to communicate known or foreseeable risks, courts should be guided by recently developed standards governing informed consent to surgery and other medical treatment. ${ }^{\top 7}$ Increasingly, those cases measure the adequacy of disclosure not by the traditional rules defining medical negligence ${ }^{78}$ but by what a reasonable person would need to know in deciding whether to undergo treatment. ${ }^{79}$

A similar standard should be applied to measure a physician's duty to disclose genetic risks. ${ }^{80}$ Although doctors in the contexts of both informed consent and genetic counseling are not to make the ultimate choice among various courses of action, ${ }^{81}$ they possess information that

birth they would have prevented had they known of the child's minor birth defects or sex. The court in Zepeda v. Zepeda, 41 Ill. App. 2d 240, 260, 190 N.E.2d 849, 858 (1963), cert. denied, 379 U.S. 945 (1964), denied a cause of action brought on behalf of an illegitimate child against his father on the ground that upholding such claims would encourage the bringing of suits by "all others born into the world under conditions they might regard as adverse." Similarly, the award of damages to parents of children with only minor defects might foster suits brought by parents of any "less than ideal" children. So long as one assumes that a reasonable person would not choose to abort selectively on the basis of sex or of the presence of minor defects in the fetus, recognition of such claims can be avoided simply by limiting the required amount of disclosure by physicians to those genetic risks that a reasonable prospective parent would want to know in making procreative decisions. See pp. 1507-08 infra.

77. See Capron, supra note 30, at 588-94 (discussing relationship between law of informed consent and "informed decisionmaking in genetic counseling"). For contrasting commentary on recent judicial criteria for informed consent, see generally Capron, $I n$ formed Consent in Catastrophic Disease Research and Treatment, 123 U. PA. L. REV. 340 (1974); Goldstein, For Harold Lasswell: Some Reflections on Human Dignity, Entrapment, Informed Consent, and the Plea Bargain, 84 YALE L.J. 683, 690-98 (1975); Riskin, Informed Consent: Looking for the Action, 1975 U. ILL. L.F. 580.

78. This standard is interpreted to require the disclosure that a reasonable physician would make in similar circumstances. See, e.g., Green v. Hussey, 127 Ill. App. 2d 174, 262 N.E.2d 156 (1970); Natanson v. Kline, 186 Kan. 393, 350 P.2d 1093, rehearing denied, 187 Kan. 186, 354 P.2d 670 (1960).

79. See, e.g., Canterbury v. Spence, 464 F.2d 772, 787, 792 (D.C. Cir.), cert. denied, 409 U.S. 1064 (1972) (materiality of information to be disclosed need not be established by expert testimony); Wilkinson v. Vesey, 110 R.I. $606,627-28,295$ A.2d 676, 689 (1972) (some factors relevant to this determination are "severity of the risk and the likelihood of its occurrence"). Although this means that there are limits on what a physician must disclose, see, e.g., Scaria v. Saint Paul Fire \& Marine Ins. Co., 68 Wis. 2d 1, 12-13, 227 N.W.2d 647, 653 (1975) (no need to give "detailed technical medical explanation" or to disclose "extremely remote possibilities" among several suggested limits), it is clear that the exceptions to the general principle of disclosure must be drawn narrowly if informed consent is to have any significance.

80. An action based on a lack of informed consent to pregnancy was expressly denied in Karlsons v. Guerinot, 57 App. Div. 2d 73, 81-82, 394 N.Y.S.2d 933, 938-39 (1977), a case in which a physician's failure to warn prospective parents of their genetic risk had allegedly resulted in the birth of a child with Down's Syndrome. That court distinguished the traditional informed consent cases on the ground that the injury in such cases "arose from some affirmative violation of the patient's physical integrity." Id. at 82, 394 N.Y.S.2d at 939. The informed consent analogy should not have been rejected in Karlsons since prospective parents nced to know their genetic risks in order to make childbearing plans, in much the same way as a patient needs to know the medical risks inherent in either undergoing or refusing treatment.

81. See Cobbs v. Grant, 8 Cal. 3d 229, 242, 502 P.2d 1, 9, 104 Cal. Rptr. 505, 513 (1972) (stating as axiomatic patient's right to choose course of treatment); Schloendorff v. Society 
deciders often cannot otherwise easily obtain. ${ }^{82}$ Indeed, it is usually only through physician disclosure that prospective parents will be given the opportunity to act to avert the birth of children with genetic defects. ${ }^{83}$ Thus doctors should be required to inform prospective parents of all the genetic risks ${ }^{84}$ and reproductive options that a reasonable person would want to know in deciding whether to procreate. ${ }^{85}$

of N.Y. Hosp., 211 N.Y. 125, 105 N.E. 92 (1914) (individual's right to determine what happens to his body), overruled on other grounds, Bing v. Thunig, 2 N.Y.2d 656, 143 N.E.2d 3, 163 N.Y.S.2d 3 (1957); pp. 1495-96 supra (prospective parents should have right to make ultimate procreative decisions).

82. In the area of informed consent, the physician's greater knowledge has meant that his duty to disclose is not limited to answering a patient's questions. See Canterbury $\mathrm{v}$. Spence, 464 F.2d 772, 783 n.36 (D.C. Cir.), cert. denied, 409 U.S. 1064 (1972). The court in Park v. Chessin, 60 App. Div. 2d 80, 84-87, 400 N.Y.S.2d 110, 112-14 (1977), refused to dismiss causes of action based on the physicians' negligently telling prospective parents that there was no chance that the polycystic kidney disease that had killed their first child would recur; the true risk was one in four. It may have drawn an inappropriate line, however, when it distinguished Howard v. Lecher, 42 N.Y.2d 109, 366 N.E.2d 64, 397 N.Y.S.2d 363 (1977), on the ground that the Howard parents had not actually asked about the possibility that their children might have Tay-Sachs disease. Although physicians are not and cannot be insurers of "genetic health," see pp. 1504-06 supra, the dissenting judge in Howard convincingly argued that Dr. Lecher had breached the medical standard of care in failing to suggest that tests were available to detect both the parents' risk of this disorder and its possible occurrence in their unborn children. 42 N.Y.2d at 114-15, 366 N.E.2d at 67, 397 N.Y.S.2d at 366-67 (Cooke, J., dissenting).

83. It is possible that prospective parents might learn of certain of their genetic risks from family planning or genetic screening programs. See pp. 1494, 1498 \& notes 27, 39-40 supra.

84. Some of the specific factors to be considered in measuring the foreseeable relevance of a particular genetic risk would include: the burden of the defect (compare Down's Syndrome, which is inevitably associated with mental retardation, see note 15 supra, with PKU, in which mental retardation can be averted by the use of a special diet, see note 14 supra); the likelihood of its occurrence (compare $50 \%$ or $75 \%$ risk that a dominant trait will be passed on, see IV. FuhrmanN \& F. VoGEL, supra note 16, at 17-24, with one to two percent risk of Down's Syndrome in women aged 40 to 45 , see note 16 supra); and whether the defect can be detected in utero (compare Tay-Sachs disease, which can be detected by amniocentesis, see note 21 supra, with cystic fibrosis, which cannot, see note 25 supra). In applying the standard of adequate genetic risk disclosure, courts should also require that physicians attempt to overcome the difficulties often encountered in conveying this type of information. See p. 1495 \& note 29 supra.

85. At least two of the exceptions to the informed consent requirement should be either severely restricted or rejected in the context of genetic counseling. Although a patient can waive his right to the information necessary for the exercise of an informed consent to treatment simply by saying that he does not want to know, see Cobbs v. Grant, 8 Cal. $3 \mathrm{~d}$ 229, 245, 502 P.2d 1, 12, 104 Cal. Rptr. 505, 516 (1972), the social interest in ensuring that prospective parents have access to genetic risk information suggests that a waiver of genetic counseling should be accomplished only through written refusal by the prospective parents in a manner that amply demonstrates their knowledgeable decision to waive counseling.

A physician may invoke therapeutic privilege as a defense to an alleged failure to obtain informed consent by saying that the anxiety of a patient who knew about the medical risks of treatment would have vitiated any beneficial effects of the procedure. See, e.g., Wilkinson v. Vesey, 110 R.I. 606, 628, 295 A.2d 676, 689 (1972). Whatever the merits of such assertions in the area of informed consent to treatment, there can be no situation in which a physician can justifiably withhold genetic counseling on the ground that prospective parents would be "better off" without such knowledge. 


\section{The Subjective Parent-The Requirement of Proximate Cause}

Even though parents may be able to prove that their physicians negligently failed either to detect or to disclose genetic risks, their suits should fail unless they can show that the doctors' acts proximately caused their defective children to be born. ${ }^{86}$ In the area of informed consent, proximate cause is established by showing that the injury was a foreseeable risk of the treatment given ${ }^{87}$ and that a reasonable person, properly informed of the medical dangers associated with the available procedures and with nontreatment, would not have submitted to the procedure. ${ }^{88}$ Such an "objective" standard is meant to protect physicians $^{80}$ from particular patients' testimony that had they been better informed they would have refused the treatment. ${ }^{90}$

Whatever merits such an objective rule of proximate causation may have in informed consent cases generally, ${ }^{91}$ there is little reason for its extension to cases involving genetic counseling. The interests of physicians are adequately protected by the objective standard of disclosure; the doctors should be required, at minimum, to disclose those risks that would be relevant to a reasonable person. Rather than the stringent

86. Cf. Smith v. United States, 392 F. Supp. 654, 655 (N.D. Ohio 1975) (Texas law) (maternal rubella; since physician could not have enabled child to be born healthy, his failure to warn parents had not proximately caused child's injury).

87. See, e.g., Canterbury v. Spence, 464 F.2d 772, 781, 791-92 (D.C. Cir.), cert. denied, 409 U.S. 1064 (1972); Bowers v. Garfield, 382 F. Supp. 503, 505-06 (E.D. Pa. 1974).

88. This "reasonable person" standard was adopted in three landmark decisions handed down in 1972, Canterbury v. Spence, 464 F.2d 772, 790-91 (D.C. Cir.), cert. denied, 409 U.S. 1064 (1972); Cobbs v. Grant, 8 Cal. 3d 229, 245, 502 P.2d 1, 11-12, 104 Cal. Rptr. 505̆, 51516 (1972); Wilkinson v. Vesey, 110 R.I. 606, 628-29, 295 A.2d 676, 690 (1972), and has been adopted in other jurisdictions, see, e.g., Bowers v. Garfield, 382 F. Supp. 503, 505-06 (E.D. Pa. 1974); Scaria v. Saint Paul Fire \& Marine Ins. Co., 68 Wis. 2d 1, 13-15, 227 N.W.2d 647, 654-55 (1975).

89. The courts often expressly stated their unwillingness to place "the physician in jeopardy of the patient's bitterness and disillusionment." Cobbs v. Grant, 8 Cal. 3d 229, 245, 502 P.2d 1, 11, 104 Cal. Rptr. 505, 515 (1972); accord, Canterbury v. Spence, 464 F.2d 772, 790.91 (D.C. Cir.), cert. denied, 409 U.S. 1064 (1972); Scaria v. Saint Paul Fire \& Marine Ins. Co., 68 Wis. 2d 1, 15, 227 N.W.2d 647, 655 (1975).

90. Indeed, the content of a patient's testimony on this issue may even be deemed to have no significance. See Hamilton v. Hardy, 549 P.2d 1099, 1105 (Colo. App. 1976), cert. denied, id. (fact that plaintiff had not testified as to whether she would have stopped using "Pill" had she known of risks involved irrelevant); Fogal v. Genesee Hosp., 41 App. Div. 2d 468, 474, 344 N.Y.S.2d 552, 560 (1973) (dictum) (patient's testimony not dispositive even had she said that she would have had surgery anyway). But see Holt $\mathrm{v}$. Nelson, 11 Wash. App. 230, 236, 523 P.2d 211, 216 (1974) (patient's testimony relevant as part of evidence in spite of its self-serving nature).

91. There have been suggestions in the literature that the application of an "objective" standard of proximate cause in informed consent cases is too harsh on plaintiff patients. See, e.g., Capron, supra note 77, at 420-23 (subjective test); Riskin, supra note 77, at 600-06 (either remove proximate cause requirement altogether or require "showing that [patient] might have withheld consent"); Comment, Informed Consent After Cobbs-Has the Patient Been Forgotten?, 10 SAN Diego L. REv. 913, 924-27 (1973) (subjective test). 
standard derived from informed consent cases, a more subjective proximate cause requirement should be adopted in the genetic counseling context. Parents should be required only to show that they would not have had the children concerned had they known of their foreseeable genetic risks; the obvious evidentiary problems entailed by this standard are a necessary aspect of preserving parental autonomy in procreative decisionmaking. ${ }^{92}$

\section{The Physician as Conscientious Objector}

In suits brought for failure to provide information about genetic risk, physicians with religious objections to the use of contraception or abortion ${ }^{93}$ may raise the defense that imposition of tort liability would coerce their involvement in decisions that result in action repugnant to their convictions. Such physicians cannot be required to perform contraceptive sterilization or abortion operations. ${ }^{94}$ Yet a doctor's conscientious refusal to disclose information about genetic risk to prospective parents effectively forecloses their informed procreative decisionmaking. Except where the risks have been uncovered in a genetic screening program, prospective parents are not likely to learn of such possibilities except through doctors' warnings. ${ }^{95}$ By contrast, per-

92. By the time of trial, the parents might well have found the reality of having a genetically defective child much more burdensome than they would have believed had they been warned prior to the child's birth. Yet when a person's recollection of a prior occurrence may be colored by after-the-fact events, courts have often let such considerations go only to the weight of his testimony, leaving to the factfinder the task of discerning its truth. Chief Justice Weintraub, dissenting in part to the landmark decision in Gleitman v. Cosgrove, 49 N.J. 22, 63, 227 A.2d 689, 711 (1967), implicd this approach for parental testimony that they would have obtained an abortion had they known that their unborn child might be injured by maternal rubella. Contra, Rieck v. Medical Protective Co., 64 Wis. 2 d 514, 519, 219 N.W.2d 242, 245 (1974).

93. See, e.g., Padin v. Fordham Hosp., 392 F. Supp. 447, 448 (S.D.N.Y. 1975) (tubal ligation not performed at time of plaintiff's Caesarean section because anesthesiologist said that contraceptive sterilization contravened his beliefs as Roman Catholic); Karlsons v. Guerinot, 57 App. Div. 2d 73, 83-84, 394 N.Y.S.2d 933, 940 (1977) (physician stated his religious objection to abortion).

94. The Church Amendment, passed by Congress in 1973, protects the rights of individuals and hospitals to refuse to provide nontherapeutic abortion and contraceptive sterilization operations where to do so would contravene their "religious beliefs or moral convictions." Health Programs Extension Act of 1973, Pub. L. No. 93-45, 87 Stat. 95 (1973), as amended by National Research Act, Pub. L. No. 93-348, 88 Stat. 353 (1974) (codified at 42 U.S.C. $\$ 300 a-7$ (Supp. V 1975)). The right of a conscientiously objecting physician not to participate in abortion or contraceptive stcrilization operations has never been directly litigated but was assumed in Doe v. Bolton, 410 U.S. 179, 197-98 (1973) (abortion), and in Padin v. Fordham Hosp., 392 F. Supp. 447, 448 (S.D.N.Y. 1975) (contraceptive sterilization).

95. Prospective parents who justifiably fear that their children might be born defective may nonetheless rely on the negligently given reassurances of their physicians. See, e.g., Park v. Chessin, 88 Misc. 2d 222, 224-25, 387 N.X.S.2d 204, 206-07 (Sup. Ct. 1976) aff'd, 60 App. Div. 2d 80, 400 N.Y.S.2d 110 (1977) (polycystic kidney disease); Jacobs v. Theimer, 519 S.W.2d 846, 847 (Tex. 1975) (rubella); cf. Johnson v. Yeshiva Univ., 42 N.Y.2d 818, 
sons seeking physicians' services in connection with contraception or abortion are already aware of their needs, and the refusal of one doctor to provide these services will generally not prevent their finding another practitioner who will. ${ }^{96}$ Moreover, a requirement that physicians provide information about genetic risk is far less burdensome than one that they perform the objectionable operations themselves. Indeed, disclosure of such information may not ultimately result in the use of either contraception or abortion; prospective parents might well decide to procreate despite such a warning. In other situations, investigation might prove prospective parents' fears of specific genetic defects to be groundless, permitting them to go ahead with their childbearing plans. Yet, in the end, it may be possible to avoid even this limited intrusion on the physicians' religious convictions.

To serve legitimate needs of prospective parents, courts need not require objecting doctors either to undertake techniques to ascertain a person's genetic risk or even to provide prospective parents with genetic counseling. Instead, courts should require such physicians to conform to the standard of care exercised by other doctors in uncovering indications that prospective parents among their patients may be at genetic risk and to suggest that those patients go to other doctors to obtain any necessary additional testing and counseling. ${ }^{97}$ Although even

819, 364 N.E.2d 1340, 1341, 396 N.Y.S.2d 647, 647 (1977) (cri-du-chat syndrome; failure to perform amniocentesis). The inequality of knowledge between the doctor and the prospective parents should counter any allegation that the latter's failure to seek out genetic counseling constitutes contributory negligence. Similarly, in Martineau v. Nelson, 247 N.W.2d 409 (Minn. 1976), an inadequately performed tubal ligation had resulted in an unplanned childbirth. On appeal, the court held that the jury's finding that the husband had been $50 \%$ contributorily negligent in not obtaining a vasectomy was not justified. Id. at 416.17 . The court stated that because the physicians had superior knowledge, their giving conflicting advice on the advisability of his undergoing sterilization had breached an obligation to give clear information and advice. $I d$. at 417 .

96. Indeed, many of the courts that have permitted doctors or hospitals to refuse to perform abortion or sterilization operations expressly noted that the desired services would be available elsewhere. See, e.g., Allen v. Sisters of Saint Joseph, 361 F. Supp. 1212 (N.D. Tex. 1973), dismissed as moot, 490 F.2d 81 (5th Cir. 1974) (per curiam) (other hospitals in city would perform tubal ligation; defendant hospital's religious objection to procedure protected even though it would force plaintiff to have second operation or to be moved in traction); Watkins v. Mercy Medical Center, 364 F. Supp. 799 (D. Idaho 1973), aff'd 520 F.2d 894 (9th Cir. 1975) (physician could not force hospital to permit performance of sterilizations and abortions when such procedures were available at five other hospitals within 50-mile radius). But see Doe v. Bellin Memorial Hosp., 479 F.2d 756, 762 (7th Cir. 1973) (availability of abortions in public hospitals irrelevant in determining whether a denominational hospital should be required to permit such procedures).

97. See Milunsky \& Reilly, The "New" Genetics: Emerging Medicolegal Issues in the Prenatal Diagnosis of Hereditary Disorders, I AM. J.L. MED. 71, 76 (1975) (noting, however, that such physicians need not perform procedures such as amniocentesis themelves but must refer to doctors who will do them). 
this obligation may disturb the scruples of some practitioners, ${ }^{98}$ it is nevertheless needed to give prospective parents the opportunity to learn of their genetic risks.

\section{B. Determining the Measure of Damages}

Parents may suffer two types of compensable injuries from the birth of a defective child. The first is the net economic burden caused by the doctor's failure to provide accurate genetic risk information. To establish liability, of course, parents must prove that they would have averted the birth of the afflicted child had their physician not been negligent in failing to inform them of their genetic risk. ${ }^{09}$ An appropriate approximation of their economic injury would be the entire financial burden of raising the child, ${ }^{100}$ offset by any joy or benefit he might provide them. ${ }^{101}$ In the case of a severely defective child, this measure would produce the substantial recovery to which the parents are entitled; the benefits of having such a child would hardly be commensurate with the costs of rearing him. When a child has less serious disorders, ${ }^{102}$ however, the offset for benefits received could limit recovery to little more than the extraordinary support costs occasioned by his specific defect. ${ }^{103}$

98. Interview with Margery W. Shaw, M.D., J.D., on February 6, 1978 (notes on file with Yale Law Journal). But cf. Gordis, Childs \& Roseman, sutpra note 28, at 471 (survey showing that $41 \%$ of obstetricians who opposed abortion nonetheless favored genetic screening programs).

99. See pp. 1504-10 supra.

100. Becker v. Schwartz, 400 N.Y.S.2d 119 (App. Div. 1977), is the only case in which an appellate court has upheld the parents' cause of action "for the expenses of raising and institutionalizing the afflicted child." Id. at 120 (Titone, J., concurring in result). That court, however, did not discuss the desirability of reducing the amount of damages by any benefits the parents received from the child. Other courts have stated that the support obligations of the parents of a child with congenital or genetic defects could extend beyond the age of the child's majority. See Sherlock v. Stillwater Clinic, 260 N.W.2d 169, 176 n.11 (Minn. 1977).

101. Similar reductions have been made in cases in which parents have been awarded the economic costs of raising a healthy child born after a failure of contraception or abortion. See note 61 supra.

102. If the unwanted genetic trait is only slightly harmful or even benign, the parents should not even be allowed to state a valid cause of action. See note 76 supra.

103. Other measures of damages, perhaps taking into account the impact of the afflicted child's birth on the parents' childbearing plans, would produce a conceptually more satisfactory solution than that proposed by this Note. For example, the compensation awarded to parents who otherwise would have used selective abortion, artificial insemination by donor, or adoption to have a healthy child could be the extraordinary support expenses incurred on behalf of their afflicted child plus the difference between the benefits that will be provided by that child and those that would have been derived from the healthy child they would have had. If, however, parents would have chosen not to have children, they would recover all economic costs of raising the child they have, not merely the extraordinary support expenses, less any benefits they receive from him. Such a scheme would give parents of genetically defective children a significant incentive 
The second element of the parents' compensable injury is the emotional anguish caused by the afflicted child's birth. Although appellate courts have often been receptive to various assertions of economic damages, ${ }^{104}$ they have almost uniformly refused to compensate parents of genetically defective children for their emotional distress. ${ }^{10 \mathrm{a}}$ Until 1976, courts stated simply that these emotional injuries were too speculative to be measured. ${ }^{106}$ In Howard $v$. Lecher, ${ }^{107}$ however, the New York Court of Appeals invoked a new basis for denying recovery for such a claim. In light of its finding that the parents' anguish had been produced exclusively by their witnessing the course of their child's disorder, ${ }^{108}$ the court deemed them bystanders to the infant's suffering, ${ }^{109}$ clearly outside the narrow scope of New York's "zone of physical danger" rule setting limits on third-party recovery for emotional distress. ${ }^{110}$ If other state courts follow the lead of the New York Court of Appeals in viewing parents as bystanders to their children's suffering, parental recovery for emotional anguish would be

to testify that they would not have had any children had they known of their genetic risk in order to obtain the usually more generous recovery. Defendant physicians, on the other hand, would have little chance of proving that the parents' testimony was untrue. Thus to avoid the tremendous problems of proof that would be inherent in litigating such issues, it seems more appropriate to adopt the measure of damages suggested at p. 1512 supra.

104. See note 13 supra.

105. The exception is Karlsons v. Guerinot, 57 App. Div. 2d 73, 394 N.Y.S.2d 933 (1977) (child born with Down's Syndrome). Karlsons was decided two months before the New York Court of Appeals explicitly refused to grant emotional pain and suffering damages to the parents of a child with Tay-Sachs disease in Howard v. Lecher, 42 N.Y.2d 109, 366 N.E.2d 64, 397 N.Y.S.2d 363 (1977). Were Karlsons to be appealed, it would almost certainly be reversed.

106. Some courts have found the extent of such claims to be even more difficult to evaluate than that of other asserted injuries. The court in Jacobs v. Theimer, 519 S.W.2d 846,849 (Tex. 1975), although allowing parents to recover the medical expenses incurred in caring for a child injured by maternal rubella, refused to compensate them for their emotional pain and suffering on the ground that such an award would entail "speculation ... as to the pluses and minuses of parental mind and emotion." Accord, Park v. Chessin, 60 App. Div. 2d 80, 86, 400 N.Y.S.2d 110, 113 (1977) (impossibility of calculating cmotional distress damages).

107. 53 App. Div. 2d 420, 386 N.Y.S.2d 460 (1976), aff'd, 42 N.Y.2d 109, 366 N.E.2d 64, 397 N.Y.S.2d 363 (1977). The appellate division decision in this case has already been the subject of much commentary. See, e.g., 41 ALB. L. REv. 162 (1977); 12 NEw ENG. L. REv. 819 (1977); 38 U. PITT. L. REv. 550 (1977).

108. Melisa Howard had Tay-Sachs disease, a genetic disorder that inevitably causes death by the age of four or five years. See p. 1489 \& note 6 supra.

109. Howard v. Lecher, 42 N.Y.2d 109, 112, 366 N.E.2d 64, 66, 397 N.Y.S.2d 363, 365 (1977).

110. The standard, as set forth in Tobin v. Grossman, 24 N.Y.2d 609, 249 N.E.2d 419, 301 N.Y.S.2d 554 (1969), allows compensation for a claimant's own emotional pain and suffering and consequent physical harm only when a tortfeasor had caused him to fear for his personal safety. See also Nicderman v. Brodsky, $436 \mathrm{~Pa}$. 401, 261 A.2d 84 (1970); Waube v. Warrington, 216 Wis. 603, 258 N.W. 497 (1935). 
barred even in states with more liberal rules for bystander recovery. ${ }^{111}$

Neither barrier to compensation for emotional injury can withstand scrutiny. Damages for emotional pain and suffering are awarded in a variety of other contexts, ${ }^{112}$ and courts have failed to discern any unique problems in measuring the distress caused by the birth of children with genetic defects. Moreover, the Howard court's bystander analogy is inappropriate. The rules governing such cases reflect judicial fear of imposing unlimited liability on negligent tortfeasors. ${ }^{113}$ When the parents of a genetically defective child seek to recover damages, however, there is no danger of unlimited physician liability; if the child is not allowed to recover damages for his claim of wrongful life and his own suffering, the parents are the only available claimants. ${ }^{114}$ Moreover, the parents of a child with genetic defects are not mere witnesses to his suffering. Rather, they are forced to realize that because of their lack of knowledge they did not act to prevent the child's birth, thus becoming unconsenting participants in causing the pain that they clearly must observe.

\section{Conclusion}

Knowledge about human genetics can often enable prospective parents to avoid the birth of defective children. Yet the courts have not

111. Parents of genetically defective children, if deemed to be bystanders, would likely be denied damages for their emotional distress even in California where the "zone of emotional shock" rule, first promulgated in Dillon v. Legg, 68 Cal. 2d 728, 441 P.2d 912, 69 Cal. Rptr. 72 (1968), is one of the most liberal bystander recovery standards in the country. The courts of that state, in applying the Dillon rule, have interpreted it to require that the claimant have witnessed the infliction of manifestly terrible injuries upon their close relatives. See Justus v. Atchison, 19 Cal. $3 d$ 564, 565 P.2d 122, 139 Cal. Rptr. 97 (1977) (plaintiff fathers present in delivery room during stillbirths of their sons; cause of action for emotional pain and suffering denied because court found that they had not known of stillbirths until they were told by doctors); Shepard v. Porter, $76 \mathrm{Cal}$. App. 3d 16, 142 Cal. Rptr. 612 (1977) (family's causes of action stated in both strict liability and breach of warranty; child had fallen out of defective back door of stationwagon and been killed when run over by another car); Mobaldi v. Board of Regents, 55 Cal. App. 3d 573, 127 Cal. Rptr. 720 (1976) (plaintiff's cause of action sustained; her foster son, during negligently performed infusion with radioopaque dye, had become spastic, convulsant, and comatose in her arms); Jansen $v$. Children's Hosp. Medical Center, 31 Cal. App. $3 d$ 22, 106 Cal. Rptr. 883 (1973) (failure of diagnosis caused deterioration and death of child; mother's cause of action denied because she had not had sensory perception of tortious act).

112. See p. 1503 \& note 62 supra. The normal measure of damages in such cases is compensation for all the pain and suffering caused by the tortfeasor's act. See, e.g., CaliFORNIA JURY INSTRUCTIONS CiviL, $\$ \$ 12.80, .83 \& .88$ (6th rev. ed. 1977); see also IltiNoIs Pattern Jury Instructions Civil $\$ 30.05$ (2d ed. 1971 ).

113. The plaintiff in Tobin v. Grossman, 24 N.Y.2d 609, 615.17, 619, 249 N.E.2d 419, 422-24, 301 N.Y.S.2d 554, 558-61 (1969), a mother who had heard an automobile accident that had seriously injured her young child, was denied recovery for her emotional distress because the court could see no logical way to avoid extending compensation to cven casual, but sensitive, bystanders once such an award had been made.

114. See pp. 1500-03 \& note 63 supra. 


\section{Genetic Counseling}

met the challenge presented by suits brought against physicians whose failure to provide adequate counseling had allegedly caused such children to be born. The judicial reluctance to establish consistent guidelines for the imposition of tort liability and to award adequate damages has inhibited the vindication of the social interest in ensuring that prospective parents have access to such information. This Note proposes that the parents of a genetically defective child should have a cause of action when they can show that the doctor knew or, acting within the standard of care of similarly situated practitioners, should have known of the risk of that disorder, that he should have foreseen that such information would be relevant to a reasonable person, and that had these parents known of this possibility, they would not have had that child. Once these requirements have been met, the parents should be awarded substantial damages for their emotional anguish and economic injury. 